\title{
Tumor Necrosis Factor Can Induce Fever in Rats without Activating Protein Breakdown in Muscle or Lipolysis in Adipose Tissue
}

\author{
Isis C. Kettelhut and Alfred L. Goldberg \\ Department of Physiology and Biophysics, Harvard Medical School, Boston, Massachusetts 02115
}

\begin{abstract}
Tumor necrosis factor (TNF, cachectin) is a macrophage product that has been suggested to signal the loss of body weight, the decrease in adipose tissue and muscle mass, and anorexia during infections or chronic illness. To test this possibility, young growing rats were injected subcutaneously or intraperitoneally with human or murine recombinant TNF. After 3-4 h, these animals developed a $1-2^{\circ} \mathrm{C}$ fever which lasted $\sim 4 \mathrm{~h}$. With repeated daily TNF injections for $5 \mathrm{~d}$, the animals developed fevers similarly each day. In contrast, rats injected with endotoxin show a single febrile episode and then are tolerant to subsequent daily injections of endotoxin (but do not develop tolerance to TNF or interleukin-1).

On the first day of TNF treatment, the rats did not grow, but on subsequent days, despite their fevers, they grew at similar rates as controls. Although the TNF-treated rats consumed slightly less food than control animals, the ratio of growth per amount of food intake was identical in the two groups. When rats are administered endotoxin, they develop a fever, and their muscles show increased protein degradation and prostaglandin (PG)E $E_{2}$ production. However, when fevers were induced with TNF, there was no change in muscle proteolysis or $\mathbf{P G E}_{2}$ production, and in adipose tissue no increase in basal or catecholamine-induced lipolysis. Also TNF addition in vitro did not enhance lipolysis in epididymal fat pads or proteolysis in soleus muscles. Thus, TNF treatment can induce fever without producing a catabolic state similar to that induced by endotoxin.
\end{abstract}

\section{Introduction}

Tumor necrosis factor (TNF) ${ }^{1}$ is a protein produced by mononuclear phagocytes that can cause hemmorhagic necrosis of certain tumors in animals (1). One of the intriguing properties of TNF is that it has cytotoxic and cytostatic activities against various transformed cells, but has little or no effect on normal cells in culture (2-5). Recently, human and mouse TNF has been purified to homogeneity (6), cloned, and expressed in Escherichia coli $(7,8)$. As a result, highly purified recombinant TNF has become available for experimental studies and for therapeutic applications. Most studies of this molecule have focused on its anticancer properties, and its normal functions in vivo are still unclear. In its structure and biological activi-

Received for publication 15 May 1987 and in revised form 21 December 1987.

1. Abbreviations used in this paper: EDL, extensor digitorum longus (muscle); rh, recombinant human; TNF, tumor necrosis factor.

J. Clin. Invest.

(c) The American Society for Clinical Investigation, Inc.

0021-9738/88/05/1384/06 \$2.00

Volume 81, May 1988, 1384-1389 ties, TNF is similar to lymphotoxin, a product of lymphocytes which is also called $\beta$-TNF (9). Although specific receptors for TNF or lymphotoxin are present on a wide range of tissues (10-12), the actions of TNF on most of these cell types have not been established. TNF appears to be identical to cachectin, a factor isolated by Beutler and colleagues $(13,14)$ from medium of murine macrophages. This polypeptide is capable of suppressing in 3T3-L1 adipocytes (15) the activity of lipoprotein lipase and the synthesis of enzymes involved in fatty acids biosynthesis (16). On this basis, they suggested that TNF signals the loss of adipose mass and body weight (i.e., the cachexia) that accompanies chronic infections and other chronic disease states $(17,18)$. TNF has also been implicated as a primary mediator in shock as seen in gram-negative septicemia $(19,20)$. Because it can stimulate collagenase and prostaglandin $(P G) \mathrm{E}_{2}$ production by human synovial cells and dermal fibroblasts (21) with even greater potency than interleukin (IL) 1, TNF may also play a role in local inflammation. In fact, many other bioactivities initially ascribed to IL-1, including fever (22), bone resorption (23), and protein breakdown in skeletal muscle (24), may actually be attributable to TNF/cachectin.

The present studies were undertaken to evaluate critically the ability of TNF to induce a catabolic state as seen in sepsis in vivo. Previous studies have shown that rats administered $E$. coli endotoxin develop fevers that are most pronounced 2-3 $\mathrm{h}$ after the injection. By 8-12 h after the lipopolysaccharide (LPS) was administered (25), these animals showed a large increase in muscle protein degradation and $\mathrm{PGE}_{2}$ production. Because TNF is generated by macrophages after endotoxin injection (1), and because of the suggestion that TNF/cachectin stimulates lipid and protein catabolism $(17,18,26)$ and signals the onset of cachexia, we investigated the effects of recombinant TNF administration to rats on body temperature, growth, and food consumption. In addition, we examined rates of protein breakdown and prostaglandin production in muscles from these animals, as well as lipolytic activity of their adipose tissue.

\section{Methods}

Young male rats of the CD strain (50-70 g) (Charles River Breeding Laboratories, Inc., Wilmington, MA) were nourished on Purina Lab Chow (Ralston Purina Co., St. Louis, MO) and water ad libitum, and were housed in a room whose temperature was maintained constant at $74^{\circ} \mathrm{F}$. Initial injections of TNF, IL-1, or endotoxin were given at 9:00 a.m. and at subsequent times, as indicated in the captions. The animals were killed by decapitation $4,6,12$, and $24 \mathrm{~h}$ after intraperitoneal (i.p.) or subcutaneous (s.c.) TNF administration or phosphate-buffered saline (PBS) injection (control rats). The soleus and extensor digitorum longus (EDL) muscles were excised from these animals, dissected, and incubated as previously described (27). Rates of protein synthesis, protein degradation, and net protein degradation were measured as described previously $(28,29)$. Also, soleus, and EDL muscles from normal rats killed by cervical dislocation were incubated directly with 
human or murine recombinant TNF for $2 \mathrm{~h}$, and net protein breakdown was evaluated by the rate of tyrosine production from cell proteins (30). The production of $\mathrm{PGE}_{2}$ was estimated by radioimmunoassay of the amount released into the incubation medium by muscle as described previously (31).

Epididymal fat pads obtained from rats injected with TNF or PBS 4 $\mathrm{h}$ before were preincubated during $30 \mathrm{~min}$ prior to the final 2-h incubation. Fragments of this tissue were incubated at $37^{\circ} \mathrm{C}$ in KrebsRinger bicarbonate buffer containing 3\% bovine albumin (fatty acidand globulin-free, Sigma Chemical Co., St. Louis, MO) with constant shaking. Aliquots from the incubation medium were taken for determination of glycerol content (32). Also, epididymal fat pads from normal rats were incubated in vitro with human TNF or with norepinephrine $(20 \mu \mathrm{g} / \mathrm{ml})$ to stimulate lipolysis, using the same procedure described above.

The rectal temperature of the animals was followed with a digital thermometer model 49TA (Yellow Springs Instrument Co., Inc., Yellow Springs, $\mathrm{OH}$ ), which is sensitive to $0.01^{\circ} \mathrm{C}$. The animals were picked up gently and held manually during the temperature measurements. Prior to injection with monokines, body temperature of the rats was constant (data not shown). The blood was collected after decapitation, and the plasma glucose levels were measured in a glucose analyzer (Beckman Instruments, Inc., Palo Alto, CA). Another group of rats was used for measurement of food consumption and body weight after daily s.c. TNF or saline injections consecutively for $5 \mathrm{~d}$.

Recombinant human (rh) TNF and IL-1 were gifts of Biogen Research Corporation (Cambridge, MA) and BASF (Ludwigshafen, Federal Republic of Germany). The murine recombinant TNF was provided by Dr. Walter Fiers (University of Ghent). They were diluted in PBS. These solutions contain $<0.12 \mathrm{ng} / \mathrm{ml}$ of endotoxin. The endotoxin used was LPS E. coli 0.111:B4 from List Biological Laboratories (Campbell, CA).

Data presented are the means \pm SEM, and statistical analysis used the Student's $t$ test.

\section{Results}

Febrile response to $T N F$. It has been proposed that TNF released during infections induces a cachectic state characterized by anorexia, loss of body weight, and reduction in mass of adipose tissue and skeletal muscle $(17,18,26)$. To test this suggestion and to define more precisely the physiological actions of TNF, young rats (60-70 g) were treated with murine recombinant TNF or rhTNF, and the effects on body temperature, food consumption, and growth were studied.

Injection (i.p.) of human TNF $\left(10^{5} \mathrm{U} / \mathrm{g}\right.$ or $4 \mathrm{mg} / \mathrm{kg}$ body weight) caused a rise in body temperature within $3 \mathrm{~h}$. By $6 \mathrm{~h}$, the temperature of these rats began to fall and by $24 \mathrm{~h}$ these values had returned to normal $\left(36.5^{\circ} \mathrm{C}\right)$. Injection (s.c.) of this amount of TNF also caused an increase in the rats' temperature, which was maximal $4 \mathrm{~h}$ later (Fig. 1), and by $7 \mathrm{~h}$ fell to about normal (Fig. 1). A TNF dose (s.c.) of $5 \times 10^{2} \mathrm{U} / \mathrm{g}$ or 20 $\mu \mathrm{g} / \mathrm{kg}$ body weight was sufficient to raise the temperature significantly $\left(0.7 \pm 0.1^{\circ} \mathrm{C}\right)$, but higher fevers $\left(1.9 \pm 0.2^{\circ} \mathrm{C}\right)$ were observed after s.c. injection of $10^{5} \mathrm{U} / \mathrm{g}$, as shown in Fig. 1. Injection of recombinant murine TNF caused a similar rise in body temperature as did this dose of rhTNF (data not shown).

Fever induced by IL-1 requires the production of PGs (22, $33,34)$ and can be blocked with cyclooxygenase inhibitors (22). Similarly, the fever induced by murine or human TNF could be blocked totally by administering i.p. indomethacin ( 3 $\mathrm{mg} / \mathrm{kg}$ body weight), an inhibitor of the arachidonic acid cyclooxygenase, $2 \mathrm{~h}$ before the TNF. Thus, prostaglandins also seem to mediate the fever produced by TNF, and in many cell types, TNF induces $\mathrm{PGE}_{2}$ production (21). TNF is known to be quite sensitive to heat inactivation $(3,35)$, unlike endo-

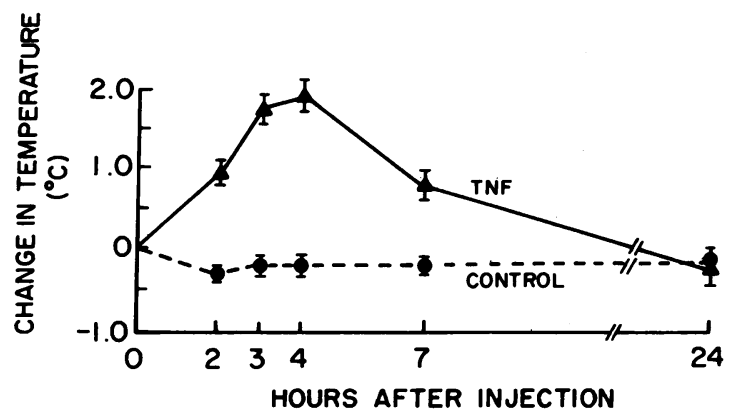

Figure 1. Changes in body temperature in rats injected s.c. with either $\operatorname{rhTNF}(4 \mu \mathrm{g} / \mathrm{g})$ or PBS (control). The real temperatures at the beginning of the experiment were $36.9^{\circ} \mathrm{C} \pm 0.2$ for the control rats and $36.6^{\circ} \mathrm{C} \pm 0.4$ for the treated animals. Each point is the mean of data obtained from six TNF-treated and six control rats. Similar results were obtained in four analogous experiments.

toxin, which is heat stable. When TNF solution was heated to $70^{\circ} \mathrm{C}$ for $15 \mathrm{~min}$, its pyrogenic activity was lost. Thus, the fever was not due to contamination of the TNF by endotoxin.

When similar TNF injections were administered once per day for $5 \mathrm{~d}$, similar changes in body temperature occurred on each day. Thus, the animals do not become readily resistant to the pyrogenic effect of TNF. These findings differ from those obtained when endotoxin is injected repetitively (Fig. 2). After an initial febrile response to s.c. injection of endotoxin, the rats failed to develop fevers when injected on subsequent days with endotoxin. However, after an interruption in these injections for three days, the animals again developed fevers when injected with endotoxin (data not shown).

In analogous experiments, we administered the animals $\beta \mathrm{IL}-1(100 \mu \mathrm{g} / \mathrm{kg})$ intravenously (i.v.) each day for $5 \mathrm{~d}$, and

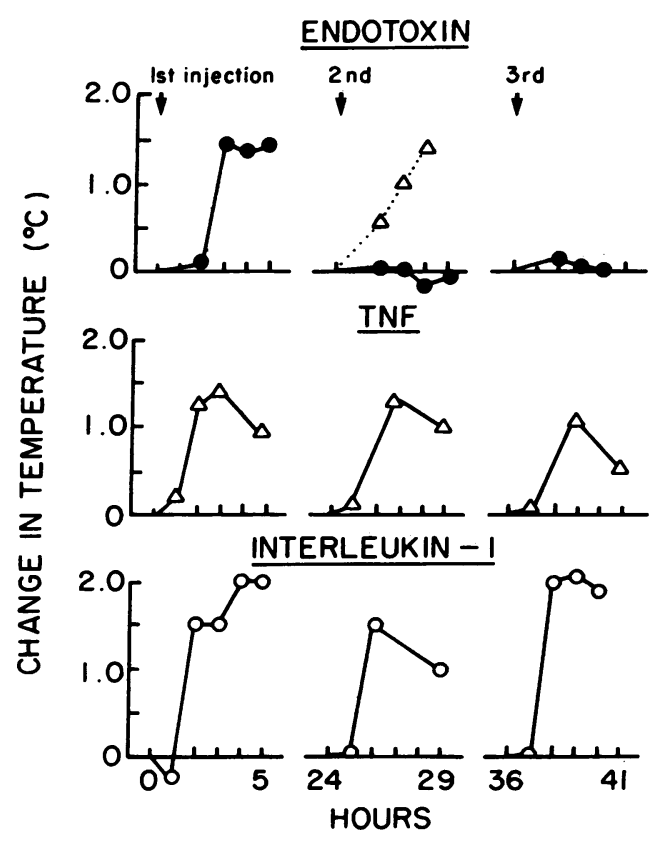

Figure 2. Mean fevers in rats injected daily with $E$. coli LPS ( 50 $\mu \mathrm{g} / \mathrm{kg}$ body weight), rhTNF ( $4 \mathrm{mg} / \mathrm{kg})$ and $\mathrm{rIL}-1 \beta(100 \mu \mathrm{g} / \mathrm{kg})$. LPS and TNF were injected s.c., and IL-1 i.v. into the jugular vein after dilution in PBS. In addition, some of the endotoxin-treated animals, on the second day, received TNF (s.c.); these animals developed fever, despite their resistance to endotoxin. Six rats were injected with PBS or endotoxin and five rats with TNF or IL-1. 
observed a $1-2^{\circ} \mathrm{C}$ rise in body temperature after each injection (Fig. 2). Since no tolerance was observed with either TNF or IL-1, while rapid tolerance developed to endotoxin, it seems likely that this loss of responsiveness develops through some failure of the animal to produce these monokines. In accord with this idea, when TNF was injected into the animals that had received LPS, these rats developed fever normally, even though they were still resistant to endotoxin (Fig. 2).

Growth and metabolic effects. During the $24 \mathrm{~h}$ after TNF (4 $\mathrm{mg} / \mathrm{kg}$ either s.c. or i.p.) injection, there was a $33 \%$ reduction in food consumption, a temporary cessation of growth, as indicated by gain in body weight (Table I), and in some animals (Fig. 3), a net loss of weight. This temporary failure of growth may be explained in large part by the decrease in food consumption, but there must also be some additional effect of TNF (e.g., in decreasing food absorption). Interestingly, the mean carcass weights of the growing and TNF-treated groups did not differ $1 \mathrm{~d}$ after injection $(63 \pm 2$ and $60 \pm 2 \mathrm{~g}$, respectively). Therefore, the difference in their body weights probably reflects the different amounts of food present in their gastrointestinal tracts.

On subsequent days of TNF treatment, the rats showed repeated fevers. Nevertheless, they gained weight at similar rates as the control animals (Table I and Fig. 3). The TNFtreated animals consumed $20-30 \%$ less food per day than the control rats. However, as shown in Table $I$, the rate of growth and the net increase in weight relative to food intake was similar in the two groups of rats. Surprisingly, on the 2 nd d, the TNF-treated animals even appeared more efficient than controls in utilizing food for growth (Table I). In contrast, endotoxin treatment of rats of this size reduces weight gain per unit of food consumption (Fagan, J. M., and A. L. Goldberg, manuscript in preparation). Thus, TNF, in this concentration, although it reduces food intake, does not cause any clear loss of tissue mass.

Previous studies have shown that muscles from rats administered endotoxin show increased proteolysis and $\mathrm{PGE}_{2}$ production (25). Additional experiments were undertaken to test if TNF induced a similar catabolic state. At various times after i.p. or s.c. TNF injection, the soleus and EDL muscles were removed and incubated in vitro. As shown in Table II, rates of protein synthesis and degradation were unchanged in muscles from rats injected $4 \mathrm{~h}$ earlier with TNF, even though these animals were febrile. In addition, the muscles did not show increased rates of $\mathrm{PGE}_{2}$ production (Table II). Also, 6,
12, or $24 \mathrm{~h}$ after TNF administration, no changes in either protein balance or in $\mathrm{PGE}_{2}$ production were found $(P>0.1)$. In addition, the rats that received daily i.v. $(0.1 \mathrm{mg} / \mathrm{kg})$ or s.c. ( $4 \mathrm{mg} / \mathrm{kg}$ ) injections of TNF for $5 \mathrm{~d}$ and developed fever on each day, also did not show any increase in protein degradation in the soleus excised $6 \mathrm{~h}$ after the fifth TNF injection. Furthermore, muscles incubated for several hours with TNF $\left(10^{4}\right.$ or $\left.10^{5} \mathrm{U} / \mathrm{ml}\right)$ do not show any changes in net proteolysis compared with control tissues (data not shown, see accompanying paper). Thus, TNF does not appear to affect muscle protein degradation either directly or indirectly at these concentrations.

In related studies, rats were administered i.v. with recombinant human $\beta$-IL-1 $(0.1 \mathrm{mg} / \mathrm{kg}$ body weight) for $5 \mathrm{~d}$. Although they developed fever on each day (Fig. 2), they also did not show changes in muscle protein breakdown after the fifth injection, as discussed in the accompanying article.

Since TNF can prevent the growth and differentiation of adipocytes from fibroblasts (36), we tested whether TNF had catabolic effects on fully differentiated adipose tissue. The epidydimal fat pads from animals that received TNF or saline $4 \mathrm{~h}$ earlier were incubated in vitro for $2 \mathrm{~h}$. TNF treatment did not stimulate lipolysis, as shown in Table III. When epidydimal fat pads from normal rats were incubated directly with TNF (4 $\mu \mathrm{g} / \mathrm{ml}$ ) for 2 or $3 \mathrm{~h}$, no effect on lipolysis was also observed (Table III). In these different experiments, the adipose tissue was also incubated with norepinephrine to confirm that these preparations could respond to a known stimulator of lipolysis. Although the catecholamine increased lipolysis, as expected, TNF had no such effect and also did not increase the sensitivity to this lipolytic hormone (Table III).

One other interesting observation was that plasma glucose levels in rats injected with TNF for 4 or $6 \mathrm{~h}$ before were significantly lower $(85 \pm 3 \mathrm{mg} / 100 \mathrm{ml})$ than those in control animals $(103 \pm 5 \mathrm{mg} / 100 \mathrm{ml})$. This effect can not be explained by reduced food intake because neither the control nor the TNFtreated rats ate during these experiments.

\section{Discussion}

Fever has been generally believed to result from the action of a single macrophage product, IL-1 (22). This polypeptide can act on the thermoregulatory center in the preoptic area of the anterior hypothalamus where it stimulates the synthesis of PGs, most notably $\mathrm{PGE}_{2}$. Since low amounts of TNF also induce fever in rats, and since TNF is also produced by acti-

Table I. Rat Food Intake and Weight Change after Daily s.c. Injections of Saline or TNF

\begin{tabular}{|c|c|c|c|c|c|c|}
\hline \multirow{2}{*}{$\begin{array}{l}\text { Days of } \\
\text { treatment }\end{array}$} & \multicolumn{2}{|c|}{ Growth } & \multicolumn{2}{|c|}{ Food intake } & \multicolumn{2}{|c|}{ Ratio of growth to food consumed } \\
\hline & Control & TNF & Control & TNF & Control & TNF \\
\hline & \multicolumn{2}{|c|}{$g / d$} & \multicolumn{2}{|c|}{$g / d$} & \multicolumn{2}{|c|}{$g / g$} \\
\hline 1 & $3.9 \pm 0.4$ & $0.2 \pm 0.4^{*}$ & $8.6 \pm 0.4$ & $5.8 \pm 0.3^{*}$ & $0.45 \pm 0.03$ & $0.02 \pm 0.06^{*}$ \\
\hline 2 & $4.6 \pm 0.6$ & $4.4 \pm 0.4(\mathrm{NS})$ & $9.4 \pm 0.7$ & $7.1 \pm 0.5^{\ddagger}$ & $0.47 \pm 0.04^{\ddagger}$ & $0.60 \pm 0.03$ \\
\hline 3 & $5.9 \pm 0.3$ & $5.4 \pm 0.4(\mathrm{NS})$ & $10.4 \pm 0.3$ & $8.7 \pm 0.3^{\ddagger}$ & $0.57 \pm 0.03$ & $0.61 \pm 0.05(\mathrm{NS})$ \\
\hline 4 & $6.3 \pm 0.5$ & $5.6 \pm 0.5(\mathrm{NS})$ & $13.2 \pm 0.7$ & $9.6 \pm 0.5^{\ddagger}$ & $0.48 \pm 0.03$ & $0.58 \pm 0.04(N S)$ \\
\hline 5 & $6.5 \pm 0.5$ & $5.9 \pm 0.5(\mathrm{NS})$ & $14.9 \pm 0.9$ & $12.2 \pm 0.7^{\ddagger}$ & $0.44 \pm 0.04$ & $0.50 \pm 0.04$ (NS) \\
\hline
\end{tabular}

13 rats were treated with TNF and 10 with PBS, and they were maintained in individual metabolic cages. All the animals weighed $60 \pm 3 \mathrm{~g}$ when they received the first TNF or PBS injection. The total weight gain after the first day in the control rats (23.3 \pm 1.2$)$ and in the TNF-treated groups (21.3 \pm 1.4$)$ did not differ significantly $(0.05<P<0.1)$. In fact, the slight possible difference (10\%) was due to the failure of 2 of the 13 animals to grow at normal rates. NS, no significant decrease with TNF $(P>0.2)$. $\quad * P<10^{-4} \quad * P<0.02$. 


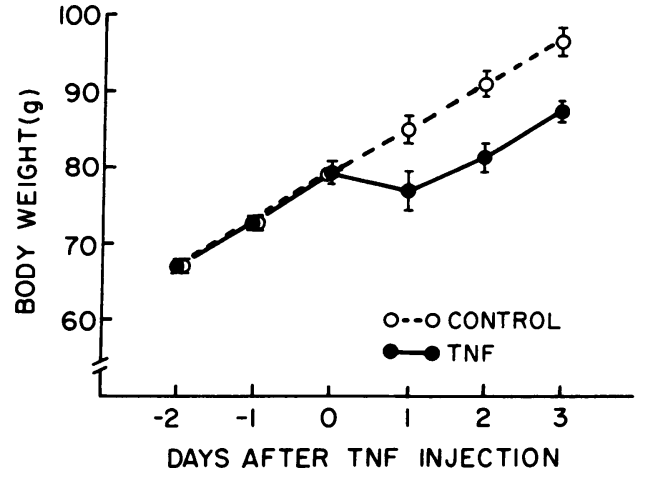

Figure 3. Body weight (g) of rats injected daily with rhTNF (4 $\mathrm{mg} / \mathrm{kg}$ ) or PBS subcutaneously. Five rats were injected with TNF and five rats with PBS.

vated macrophages, it may also contribute to the febrile response seen during infections. After these studies were completed, Dinarello et al. (34) also reported that TNF (like IL-1 and interferon [IFN]- $\alpha$ ) can cause fever and can directly stimulate hypothalamic $\mathrm{PGE}_{2}$ synthesis. Thus, induction of fever is probably not due to a single macrophage-derived substance ("endogenous pyrogen"). The several monokines with this activity, however, may all act through a final common pathway involving prostaglandins, since these responses can all be blocked with cyclooxygenase inhibitors.

The precise role of TNF in fever is uncertain since this agent can cause the release of IL-1 (34), which may help mediate the febrile response. Dinarello et al. (34) noted that when TNF $(10 \mu \mathrm{g} / \mathrm{kg})$ was injected i.v. into rabbits, a small rise in temperature occurred within $45 \mathrm{~min}$ and a later peak developed at 2-3 h, which they attributed to IL-1. No such early peak was seen in the rats studied here, after s.c., i.p. $(4 \mathrm{mg} / \mathrm{kg})$, or i.v. $(0.1 \mathrm{mg} / \mathrm{kg})$ administration, only one significant rise in temperature was observed 3-4 h later (Fig. 1). With these doses, there was a tendency for temperature to increase slightly $\left(0.4^{\circ} \mathrm{C}\right)$ 45-60 min after the injection, but this trend was not significant $(P>0.05)$. Thus, the kinetics of the fevers studied here with higher TNF doses in rats closely resemble those attributed to IL-1 in rabbits. It is noteworthy that when the same dose of TNF that is pyrogenic s.c. or i.p. is injected i.v., the rats show a large fall in temperature which is associated with shock and death within several hours (37). Surprisingly, this fall in temperature, like the febrile response, can be blocked with indomethacin (37).
Although animals quickly adapt to repeated endotoxin injections (38, Fig. 2) and after the initial episode fail to develop fever (Fig. 2), tolerance to the pyrogenic action of TNF or IL-1 was never observed. Similarly, rabbits injected daily with endotoxin develop a progressive loss of responsiveness to its pyrogenic actions, but with repeated TNF injections, they also show no decrease in febrile responses (34). This lack of tolerance to the pyrogenicity of TNF is also surprising since the rats quickly adapted to other effects of TNF injection (i.e., the failure of growth lasted only for $1 \mathrm{~d}$ after the first injection of TNF). Since the rats administered endotoxin showed tolerance to endotoxin but not to the pyrogenic actions of TNF, the decrease in the animals' responsiveness to endotoxin must involve some alteration in the macrophage that prevents the generation of TNF and/or IL-1 in response to endotoxin challenge. This lack of responsiveness may actually be an advantageous mechanism that protects the organism against high concentrations of these monokines which may lead to shock $(20,37)$.

It is well known that food consumption decreases during infectious illness, and it had been suggested that the increase in body temperature per se is responsible for the reduced appetite. However, administration of sodium salicylate can block the fever induced by endotoxin, but does not prevent the accompanying reduction in food consumption (39). Similarly, we found that TNF causes a reduction in food consumption, even when fever was prevented with indomethacin (data not shown). It is unclear whether this decreased appetite is caused directly by the TNF, because this agent can induce IL-1 production (35), which has been reported to suppress food consumption (40).

The primary conclusion of this work is that TNF does not induce cachexia at doses that produce fever. Even after the first TNF injection, when there was a temporary failure of growth, there was no weight loss in peripheral tissues (i.e., carcass). Cerami et al. (18) have reported that mice injected twice daily with concentrated medium from endotoxin-stimulated macrophages show a loss of weight and progressive decrease in food consumption. In fact, when given at low doses, this material caused weight loss in those animals despite normal food intake. Presumably, the crude macrophage medium that caused the weight loss in that study contains additional polypeptides distinct from TNF. It is also curious in those studies that the mice were reported to have normal temperature, unlike the rats studied here.

Both TNF and IL-1 have been suggested to play a role in

Table II. Protein Turnover and PGE 2 Production in Rat Soleus and EDL 4 h after Injection with Human TNF

\begin{tabular}{|c|c|c|c|c|}
\hline & Protein synthesis & Protein degradation & Net protein degradation & $\mathrm{PGE}_{2}$ production \\
\hline & & $\mathrm{nmol} / \mathrm{mg} \cdot 2 \mathrm{~h}$ & & $\mathrm{pg} / \mathrm{mg} \cdot 2 \mathrm{~h}$ \\
\hline \multicolumn{5}{|l|}{ Soleus } \\
\hline Control & $0.190 \pm 0.013$ & $0.409 \pm 0.016$ & $0.219 \pm 0.020$ & $50.8 \pm 6.9$ \\
\hline \multirow[t]{2}{*}{ TNF } & $0.192 \pm 0.007$ & $0.466 \pm 0.015$ & $0.274 \pm 0.023$ & $68.7 \pm 6.3$ \\
\hline & NS & NS & NS & NS \\
\hline \multicolumn{5}{|l|}{ EDL } \\
\hline Control & $0.158 \pm 0.011$ & $0.399 \pm 0.012$ & $0.241 \pm 0.014$ & $42.1 \pm 5.5$ \\
\hline \multirow[t]{2}{*}{ TNF } & $0.162 \pm 0.012$ & $0.343 \pm 0.015$ & $0.181 \pm 0.019$ & $47.0 \pm 5.7$ \\
\hline & NS & NS & NS & NS \\
\hline
\end{tabular}

The values represent the means \pm SEM of seven control or TNF-treated rats. NS, not significant $(P>0.1)$. 
Table III. Effect of TNF and Norepinephrine on Lipolysis by Rat Epidydimal Adipose Tissue

\begin{tabular}{ccc}
\hline & \multicolumn{2}{c}{ Glycerol release } \\
\cline { 3 - 3 } TNF & Basal & $\begin{array}{c}\text { With } \\
\text { norepinephrine }\end{array}$ \\
\hline & & $\mu \mathrm{mol} / \mathrm{g} \cdot 2 \mathrm{~h}$
\end{tabular}

Experiment A: in vitro incubation with TNF

$\begin{array}{lll}\text { Without } & 3.1 \pm 0.2 & 12.8 \pm 0.6 \\ \text { With } & 2.7 \pm 0.2 & 14.2 \pm 0.8\end{array}$

Experiment B: animals injected with TNF

$\begin{array}{lll}\text { Without } & 3.9 \pm 0.2 & 19.3 \pm 0.5 \\ \text { With } & 3.1 \pm 0.2 & 19.1 \pm 0.6\end{array}$

In experiment $A$, the epidydimal fat pad fragments from normal rats were incubated in the absence or presence of human recombinant TNF $(4 \mu \mathrm{g} / \mathrm{ml})$ and norepinephrine $(20 \mu \mathrm{g} / \mathrm{ml})$ as described in Methods. In experiment $B$, the same tissue was taken from rats injected s.c. $4 \mathrm{~h}$ prior to the experiment with TNF $(4 \mu \mathrm{g} / \mathrm{g}$ body weight) or PBS. Norepinephrine $(20 \mu \mathrm{g} / \mathrm{ml})$ was added in vitro. The values represent the means \pm SEM of five or six measurements in each situation. Similar results were obtained in two similar experiments.

cachexia and to increase muscle protein degradation. However, the negative results obtained here do not support such a view and are quite different from those obtained with partially purified human IL-1 preparations (24). There was no significant increase in muscle protein degradation, in protein synthesis or in $\mathrm{PGE}_{2}$ production after treatment in vivo or in vitro with TNF. Presumably some other monocyte factor is responsible for the increased proteolysis during infections or chronic diseases. Recent data from Moldawer (41) also suggest that TNF is not responsible for the decreased muscle protein content and synthesis observed in cancer.

Most prior studies of the metabolic effects of TNF have focused on 3T3-L1-cultured adipocytes and the expression of enzymes for triglyceride accumulation (16). There is some discrepancy in the literature concerning the effects of TNF on intracellular lipolysis in these cultured cells. Patton et al. (42) have reported that $\alpha$ TNF, $\beta$ TNF (lymphotoxin), and IFN- $\gamma$ increase fatty acid mobilization. Pekala et al. (26) have shown that medium from endotoxin-activated macrophages stimulates the hormone sensitive lipase in these cells. However, with recombinant TNF, these authors (43) failed to show any stimulation of glycerol release. The latter observations support our findings in fully differentiated adipose tissue that treatment with TNF in vitro or in vivo does not increase lipolysis or sensitivity to the lipolytic hormone, norepinephrine. (In fact, TNF may have even caused a small decrease in glycerol release.) Accordingly, several workers have reported that the lipolysis in adipose tissue decreases in shock, sepsis, and endotoxemia $(44,45)$, conditions where TNF seems to play a critical role $(19,37)$. In fact, when we increased the circulating level of TNF by i.v. injection, it caused a lethal shocklike syndrome (37), involving acidosis, hypoglycemia, and hypothermia, that seems to differ markedly from the chronic catabolic effects associated with febrile illness.

Thus, TNF does not by itself seem to account for the rapid catabolic effects observed in febrile animals administered en- dotoxin or live bacteria, and fever can be easily dissociated from the negative nitrogen balance. Therefore, these two responses seen during infection probably involve distinct signals. There may exist some particular concentrations or times of exposure to TNF that can elicit a catabolic response. In fact, after this work was completed, Oliff et al. (46) reported that mice carrying a tumor cell line that secretes TNF developed a marked weight loss (cachexia), which was only seen 14-32 d after inoculation by the cells. In accord with the present findings, no difference in weight was observed within 2 wk after tumor implantation, and no persistent weight changes were found in animals given twice daily injections of TNF. Thus, TNF may induce cachexia only after prolonged continuous exposures and may require additional tumor products. Moreover, these slow effects, which probably involve changes in gene expression, contrast sharply with the rapid alterations in protein balance occurring in infections $(24,25)$.

\section{Acknowledgments}

The authors are grateful to Ms. Brigitte Leopold for valuable technical assistance and to Mrs. Aurora Scott for assistance in preparing this manuscript. We also thank Biogen Research Corporation, Dr. Walter Fiers (Ghent), and BASF for providing us with TNF.

These studies were supported by research grants to Dr. Goldberg from the National Institute of Neurological and Communicative Diseases and the Muscular Dystrophy Association. During this work, Dr. Kettelhut held a fellowship from the Fundação de Amparo à Pesquisa do Estado de São Paulo, Brazil.

\section{References}

1. Carswell, E. A., L. J. Old, R. L. Kassel, S. Green, N. Fiore, and B. Williamson. 1975. An endotoxin-induced serum factor that causes necrosis of tumors. Proc. Natl. Acad. Sci. USA. 72:3666-3670.

2. Helson, L., S. Green, E. A. Carswell, and L. J. Old. 1975. Effect of tumor necrosis factor on cultured human melanoma cells. Nature (Lond.). 258:731-732.

3. Williamson, B. D., E. A. Carswell, B. Y. Rubin, J. S. Prendergast, and L. J. Old. 1983. Human tumor necrosis factor produced by human $\beta$-cell lines: synergistic cytotoxic interaction with human interferon. Proc. Natl. Acad. Sci. USA. 80:5397-5401.

4. Haranaka, K., N. Satomi, and A. Sakurai. 1984. Antitumor activity of murine tumor necrosis factor (TNF) against transplanted murine tumors, and heterotransplanted human tumors in nude mice. Int. J. Cancer. 34:263-267.

5. Fransen, L., J. Van der Heyden, M. R. Ruysschaert, and W. Fiers. 1986. Recombinant tumor necrosis factor: its effect and synergism with interferon-gamma on a variety of normal and transformed human cell lines. Eur. J. Cancer Clin. Oncol. 22:419-426.

6. Agarwall, B. B., W. J. Kohr, P. E. Hass, B. Moffat, S. A. Spencer, W. J. Henzel, T. S. Bringman, G. E. Nedwin, D. V. Golddel, and R. N. Harkins. 1985. Human tumor necrosis factor: production, purification and characterization. J. Biol. Chem. 260:2345-2354.

7. Shirai, T., H. Yamaguchi, H. Ito, C. W. Todd, and R. B. Wallance. 1985. Cloning and expression in Escherichia coli of the gene for human tumor necrosis factor. Nature (Lond.). 313:803-806.

8. Wang, A. M., A. A. Creasey, M. B. Ladner, L. S. Lin, J. Strickler, J. N. VanArsdell, R. Yamamoto, and D. F. Mark. 1985. Molecular cloning of the complementary DNA for human tumor necrosis factor. Science (Wash. DC). 228:149-154.

9. Pennica, D., E. Nedwin, J. S. Hayflick, P. H. Seeburg, R. Derynck, M. A. Palladino, W. J. Kohr, B. B. Aggarwal, and D. V. Goeddel. 1984. Human tumor necrosis factor: precursor, structure, expression and homology to lymphotoxin. Nature (Lond.). 312:20-27.

10. Aggarwal, B. B., T. E. Eessalu, and P. E. Hass. 1985. Characterization of receptors for human tumor necrosis factor and their regulation by interferon-gamma. Nature (Lond.). 318:665-667. 
11. Nawroth, P. P., I. Bank, D. Handley, J. Cassimeris, L. Chess, and D. Stern. 1986. Tumor necrosis factor interacts with endothelial cell receptors to induce release of interleukin-1. J. Exp. Med. 163:1363-1375.

12. Tsujimoto, M. and J. Vilcek. 1986. Tumor necrosis factor receptors in Hela cells and their regulation by interferon gamma. $J$. Biol. Chem. 261:5384-5388.

13. Beutler, B., D. Greenwald, J. D. Hulmes, M. Chang, Y-C.E. Pan, J. Mathison, R. Ulevitch, and A. Cerami. 1985. Identity of tumor necrosis factor and the macrophage secreted factor cachectin. Nature (Lond.). 361:552-554.

14. Beutler, B., and A. Cerami. 1986. Cachectin and tumor necrosis factor as two sides of the same biological coin. Nature (Lond.). 320:584-588.

15. Beutler, B., J. Mahoney, N. LeTrang, P. Pekala, and A. Cerami. 1985. Purification of cachectin, a lipoprotein lipase-suppressing hormone secreted by endotoxin-induced Raw264.7 cells. J. Exp. Med. 161:984-995.

16. Pekala, P. H., M. Kawakami, C. W. Angus, M. D. Lane, and A. Cerami. 1983. Selective inhibition of synthesis of enzymes for "de novo" fatty acid biosynthesis by an endotoxin-induced mediator from exudate cells. Proc. Natl. Acad. Sci. USA. 80:2743-2747.

17. Cerami, A. 1983. Materials which promote and inhibit the biosynthesis of cachectin, a macrophage protein which induces catabolic state: a review. In Mechanism of Drug Action. Academic Press, Inc., New York. 175-186.

18. Cerami, A., Y. Ykeda, N. LeTrang. P. J. Hotez, and B. Beutler. 1985. Weight loss associated with an endotoxin-induced mediator from peritoneal macrophages: the role of cachectin (Tumor Necrosis Factor). Immun. Lett. 11:173-177.

19. Beutler, B., I. W. Milsark, and A. Cerami. 1985. Passive immunization against cachectin/tumor necrosis factor protects mice from lethal effect of endotoxin. Science. 229:869-871.

20. Tracey, K. J., B. Beutler, S. F. Lowry, J. Merryweather, S. Wolpe, I. W. Milsark, R. J. Hariri, T. J. Fahey III, A. Zentella, J. D. Albert, G. T. Shires, and A. Cerami. 1986. Shock and tissue injury induced by recombinant human cachectin. Science (Wash. DC). 234:470-473.

21. Dayer, J. M., B. Beutler, and A. Cerami. 1985. Cachectin/ tumor necrosis factor stimulates collagenase and prostaglandin $\mathrm{E}_{2}$ production by human synovial cells and dermal fibroblasts. J. Exp. Med. 162:2163-2168.

22. Dinarello, C. 1984. Interleukin-1. Rev. Infect. Dis. 6:51-95.

23. Gowen, M., D. D. Wood, G. R. Mundy, and R. G. G. Russell. 1985. Studies on the control of Il-1 stimulated bone resorption. In The Physiologic, Metabolic and Immunologic Actions of Interleukin-1. M. J. Kluger, J. J. Oppenheim, and M. C. Powanda, editors. Alan R. Liss, Inc., New York. 85-93.

24. Baracos, V., H. Rodemann, C. Dinarello, and A. L. Goldberg. 1983. Human leukocytic pyrogen (interleukin-1) stimulates protein degradation and prostaglandin synthesis in skeletal muscle. $N$. Engl. J. Med. 308:553-558.

25. Fagan, J. M., and A. L. Goldberg. 1985. Muscle protein breakdown, prostaglandin $\mathrm{E}_{2}$ production and fever following bacterial infection. In The Physiologic, Metabolic and Immunologic Actions of Interleukin-1. M. J. Kluger, J. J. Oppenheim, and M. C. Powanda, editors. Alan R. Liss, Inc., New York. 201-210.

26. Pekala, P. H., S. R. Price, C. A. Horn, B. E. Hom, J. Moss, and A. Cerami. 1984. Model for cachexia in chronic disease: secretory products of endotoxin-stimulated macrophages induce a catabolic state in 3T3-L1 adipocytes. Trans. Assoc. Am. Physicians. 97:251-259.

27. Goldberg, A. L., S. Martel, and M. Kushmerick. 1975. In vitro preparation of the diaphragm and other skeletal muscles. Methods Enzymol. 39:82-93.

28. Fulks, R., J. Li, and A. L. Goldberg. 1975. Effects of insulin, glucose and amino acids on protein turnover in rat diaphragm. J. Biol. Chem. 250:290-298.

29. Tischler, M., M. Desautels, and A. L. Goldberg. 1982. Does leucine, leucyl tRNA or some metabolite of leucine regulate protein synthesis and degradation in skeletal and cardiac muscle. J. Biol. Chem. 257:1613-1621.

30. Waalkes, T. P., and S. Udenfriend. 1957. A fluorometric method for the estimation of tyrosine in plasma and tissues. J. Lab. Clin. Med. 50:733-736.

31. Rodemann, H., L. Waxman, and A. L. Goldberg. 1982. The stimulation of protein degradation in muscle by $\mathrm{Ca}^{2+}$ is mediated by prostaglandin $\mathrm{E}_{2}$ and does not require the calcium-activated protease. J. Biol. Chem. 257:8716-8723.

32. Korn, E. D. 1959. The assay of lipoprotein lipase in vivo and in vitro VII-5. Determination of glycerol. Methods Biochem. Anal. 7:145-192.

33. Dinarello, C., and H. A. Bernheim. 1981. Ability of human leukocytic pyrogen to stimulate brain prostaglandin synthesis in vitro. J. Neurochem. 37:702-708.

34. Dinarello, C., J. G. Cannon, S. M. Wolff, H. A. Bernheim, B. Beutler, A. Cerami, I. S. Figari, M. A. Palladino, Jr., and J. V. O’Connor. 1986. Tumor necrosis factor (cachectin) is an endogenous pyrogen and induces production of interleukin-1. J. Exp. Med. 163:14331450.

35. Kull, F. C. Jr., and Cuatrecasas, P. 1981. Preliminary characterization of the tumor cell cytotoxin in tumor necrosis serum. J. Immunol. 126:1279-1282.

36. Torti, F. M., B. Dieckmann, B. Beutler, A. Cerami, and G. M. Ringold. 1985. A macrophage factor inhibits adipocyte gene expression: an in vitro model of cachexia. Science (Wash. DC). 229:867-869.

37. Kettelhut, I. C., W. Fiers, and A. L. Goldberg. 1987. The toxic effects of tumor necrosis factor in vivo and their prevention by cyclooxygenase inhibitors. Proc. Natl. Acad. Sci. USA. 84:4273-4277.

38. Atkins, E., and C. A. Dinarello. 1985. Reflections on the mechanism of the biphasic febrile response and febrile tolerance. In The Physiologic, Metabolic and Immunologic Actions of Interleukin-1. M. J. Kluger, J. J. Oppenheim, and M. C. Powanda, editors. Alan R. Liss, Inc., New York. 97-106.

39. McCarthy, D. O., M. J. Kluger, and A. J. Vander. 1984. The role of fever in appetite suppression after endotoxin administration. Am. J. Clin. Nutr. 40:310-316.

40. McCarthy, D. O., M. J. Kluger, and A. J. Vander. 1985. The effect of peripheral and intracerebroventricular administration of interleukin-1 on food intake of rats. In The Physiologic, Metabolic and Immunologic Actions of Interleukin-1. M. J. Kluger, J. J. Oppenheim, and M. C. Powanda, editors. Alan R. Liss, Inc., New York. 171-179.

41. Moldawer, L. L. 1986. Interleukin-1, tumor necrosis factoralpha (cachectin) and the pathogenesis of cancer cachexia. Ph.D. thesis. Göteborgs Universitet, Göteborg, Sweden.

42. Patton, J. S., H. M. Shepard, H. Wilking, G. Lewis, B. B. Aggarwal, T. E. Eessalu, L. A. Gavin, and C. Grunfeld. 1986. Interferons and tumor necrosis factor have similar catabolic effects on 3T3-L1 cells. Proc. Natl. Acad. Sci. USA. 83:8313-8317.

43. Price, S. R., T. Olivecrona, and P. H. Pekala. 1986. Regulation of lipoprotein lipase synthesis by recombinant tumor necrosis factor: the primary regulatory role of the hormone in 3T3-L1 adipocytes. Arch. Biochem. Biophys. 251:738-746.

44. Daniel, A. M., M. E. Taylor, B. Kapadia, and L. D. MacLean. 1983. Metabolism of prolonged shock. Adv. Shock Res. 9:19-30.

45. Filkins, J. P. 1985. Monokines and the metabolic pathophysiology of septic shock. Fed. Proc. 44:300-304.

46. Oliff, A., D. Defeo-Jones, M. Boyer, D. Martinez, D. Kiefer, G. Vuscolo, A. Wolfe, and S. H. Socher. 1987. Tumors secreting human TNF/cachectin induce cachexia in mice. Cell. 50:555-563. 